\title{
Forestry Research Advisory Council of Canada Annual Report for 1992 May 1993
}

\section{Summary}

The Forestry Research Advisory Council of Canada (FRACC) has advised Forestry Canada on forestry research priorities and policies since 1983. This report covers the 1992 calendar year.

Forest research advisory groups now operate in most provinces as a result of the 1987 decision by the Canadian Council of Forest Ministers (CCFM). Since then, FRACC has worked with these groups to prepare an annual overview of forestry research priorities and concerns across Canada, which has been published in The Forestry Chronicle.

The 1992 Forest Congress in Ottawa was important in the evolution of Canadian forest policies. Participants deliberated on Canada's forest resources and their management with emphasis on sustainable use for all commodity and amenity values of the forest. The resulting forestry accord is a strong commitment to maintain and enhance the long-term health of Canada's forest ecosystems to benefit present and future generations. This challenge will require vigorous research and Council is pleased that the accord contains a strong commitment to research. The accord and the supporting document, Sustainable Forests, A Canadian Commitment, will guide Council in its future deliberations.

As a result of its deliberations in 1992, Council makes the following recommendations:

1. Because Canadians expect many kinds of benefits from the forest resource, Forestry Canada should increase research that will help forest managers assess all commodity and amenity values of the forest and incorporate them into integrated forest management plans.

2. To help develop multidisciplinary approaches, Forestry Canada should work with educational institutions to develop curricula for both graduate and undergraduate students that emphasize the multidisciplinary nature of forestry.

3. To help foster effective public participation in resource decisions, Forestry Canada should continue monitoring public perceptions of forestry and develop new ways of involving people in resource management decisions.

4. To assist young scientists in launching their careers, Forestry Canada should establish and sponsor annual forums where young scientists and senior management exchange ideas and information.

5. To promote steady progress in research, Forestry Canada should ensure overlap and training of replacement scientists when existing staff retire.

6. To provide a useful tool for research managers and scientists, Forestry Canada should vigorously pursue completion of the update of the forestry research inventory.

7. Because of the importance of all forestry workers' attitudes and skills in implementing sound forest management, Forestry Canada should investigate methods of training and motivation and make them part of technology transfer programs.

8. Forestry Canada research establishments should develop methods to incorporate economic and social criteria in research planning and project selection.

\section{Introduction}

Since 1983, FRACC has advised Forestry Canada on national forestry research priorities and policies. In 1987, the Canadian Council of Forest Ministers (CCFM) decided to establish forestry research advisory groups in its respective provinces or territories and asked FRACC to coordinate a Canada-wide overview of forestry research priorities and concerns. Forest research advisory groups now operate in most provinces and work with FRACC to prepare an annual overview of forestry research priorities, which is published in The Forestry Chronicle.

The Forest Congress held in Ottawa in March 1992 was important in the evolution of forest policies in Canada. Political leaders, the forest industry, nongovernment interest groups, forestry professionals, and educators deliberated on the sustainable use of Canada's forest resources. The resulting forestry accord is a strong commitment to "maintain and enhance the long-term health of our forest ecosystems, for the benefit of all living things both nationally and globally, while providing environmental, economic, social and cultural opportunities for the benefit of present and future generations." Attaining this goal will require vigorous research and the accord contains strong commitments to research. The accord and the supporting document, "Sustainable Forests, A Canadian Commitment," will guide Council as it considers future priorities and policies.

Council members in 1992 are listed in Appendix I. Three meetings were held during the year: Ottawa, January 23-24; Montreal, May 13-14; and Vancouver, September 25. Deputy Minister Jean Claude Mercier attended all meetings, and Council members appreciate his continuing interest and input and the assistance and interest of all members of Forestry Canada.

\section{Principal Issues and Concerns in 1992}

Global Trends and Issues and Implications for Research

In 1990 and 1991, Council intensively reviewed Forestry Canada's programs and by the end of 1991 had a good understanding of the agency's research program. It was concerned about the level of support for some parts of the research program and had identified an area of possible duplication of effort. Generally, though, Council found the research scientifically sound and directed at the principal forestry problems.

In 1992, Council turned its attention to the context in which Forestry Canada operates and set out to identify major national and global trends affecting forestry research needs and priorities in the nineties and beyond.

One of the most significant trends is the growing recognition of the importance of interconnections at all levels, biological, physical, and social, and the urgency of managing forests for all commodity and amenity values. A corollary is better understanding of the detrimental effects of excessive compartmentalization in resource management. This "walling off' occurs from the beginning of professional education, and perhaps even earlier, to the doctoral level. 
There is increasing focus on managing forests as ecosystems, but progress has been slow; furthermore, the interrelationships are much broader. The forest ecosystem must be viewed in the context of peoples' needs and wants. Consideration of the social aspects of forestry will become increasingly important as people become more interested, concerned, and demanding about resource management issues.

Because forestry is itself multidisciplinary, management to sustain our forest resources over the long term requires research in many disciplines ranging from demographics to biological engineering, from market studies to soil microbiology. Integrating these diverse subjects is central to understanding complex ecosystems and devising management systems for them.

Recommendation 1. Because Canadians expect many kinds of benefits from the forest resource, Forestry Canada should increase research that will help forest managers assess all commodity and amenity values of the forest and incorporate them into integrated forest management plans.

Recommendation 2. To help develop multidisciplinary approaches, Forestry Canada should work with educational institutions to develop curricula for both graduate and undergraduate students that emphasize the multidisciplinary nature of forestry.

Recommendation 3. To help foster effective public participation in resource decisions, Forestry Canada should continue monitoring public perceptions of forestry and develop new ways of involving people in resource management decisions.

\section{The Supply of Research Scientists}

Solving the difficult physical, biological, and sociological problems facing forest resource managers depends on the number and quality of the scientists tackling the problems. In 1991, FRACC met with a group of young scientists to learn about the incentives and disincentives affecting young people embarking on scientific careers and the factors that hamper their careers. As a result, FRACC made three recommendations last year suggesting (1) a study of the supply and demand for scientists in the various disciplines that make up forestry research; (2) Forestry Canada provide more summer employment opportunities for undergraduates, participate fully with the universities in cooperative programs for graduate and undergraduate students, and enhance its "apprentice" programs for recent Ph.D's; (3) Forestry Canada expand its initiative of setting aside a small fund to be used for following up quickly on promising new research approaches.

Council believes that this issue continues to be very important and has two further suggestions to help ensure the future supply of qualified, highly motivated forest scientists.

Recommendation 4. To assist young scientists in launching their careers, Forestry Canada should establish and sponsor annual forums where young scientists and senior management exchange ideas and information.

Recommendation 5. To promote steady progress in research, Forestry Canada should ensure overlap and training of replacement scientists when existing staff retire.
Inventory of Forestry Research in Canada

Dr. A.J. Kayll, while on sabbatical from Lakehead University, initiated this project some years ago in response to a suggestion by FRACC. Council has recommended that Forestry Canada maintain the inventory and make it available to managers and to researchers. The first updating conducted by the Petawawa National Forestry Institute encountered difficulties. Council believed that the questionnaire and procedures needed improvement and that full use should be made of existing research inventories being maintained in at least two provinces, British Columbia and Quebec. These improvements are under way and Council looks forward to the completion of the first full updating of the inventory.

Recommendation 6. Forestry Canada should vigorously pursue completion of the update of the forestry research inventory.

\section{Forest Science and Technology Agenda}

Council has been kept well informed on this project by having three members on the advisory group that helps guide the work. The completed report will suggest an overall framework or agenda for forestry science and technology programs in Canada and define the role of Forestry Canada within that framework. It will propose principles that should typify a forestry science and technology agenda or strategy for Canada, discuss current issues in relation to these principles, and consider the implications for the country's science and technology agencies. Council supports this initiative and urges its prompt completion.

\section{Technology Transfer and Forestry Worker Attitudes}

As noted last year, technology transfer is a persistent problem and Council is gratified that Forestry Canada is giving it a high priority. Efforts to improve two-way communication between researchers and practitioners and thus put research results into practice must continue.

Implementation of fully integrated and environmentally sound forest management will largely depend on the skills and attitudes of all forestry personnel from professional foresters to machine operators. Making them more aware of the environment and helping them to understand better how their work affects the whole forest ecosystem are very important. Some specialized research will be required on how to effect this training and motivation.

Recommendation 7. Because of the importance of all forestry workers' attitudes and skills in implementing sound forest management, Forestry Canada should investigate methods of training and motivation and make them part of technology transfer programs.

\section{Forestry Canada's Headquarters Economics Program}

At its first meeting in 1992, Council reviewed the economics program of the Policy and Economics Directorate at Forestry Canada headquarters. The staff made presentations on their work stressing that economic analysis is their first priority, not economics research. The directorate has been heavily involved in the softwood lumber dispute with the United States, taxation matters, and general industry and trade concerns. It is not involved in using economic criteria in the selection of research projects and, in fact, expressed 
doubt about the value of conventional cost/benefit analysis for this purpose. Council, however, believes it is important to incorporate some economic analysis in research planning and management and that it should be done by the economics staff at the various research establishments. Council was favorably impressed with the economics analysis work of the directorate and commends Forestry Canada for its high quality program in this area.

Recommendation 8. Forestry Canada research establishments should develop methods to incorporate economic and social criteria in research planning and project selection.

\section{Research Priorities Across Canada}

A fourth annual overview of forestry research priorities and concerns across Canada was compiled for the Canadian Council of Forest Ministers in 1992. It is based on the top five priorities for forest research identified by each provincial forestry research advisory body. FRACC chairman Jack Toovey presented the results to the CCFM at its October meeting in Saskatoon. The report was published in the December 1992 issue of The Forestry Chronicle.

The ten most important topics requiring research attention are presented here in descending priority:

1. Integrated resource management and decision support.

2. Pest and weed management and alternatives to chemicals.

3. Environmental effects of forest management.

4. Ecological knowledge for intensive forest management.

5. Forest growth and yield data.

6. Increased productivity, tree improvement, and regeneration.

7. Forest inventory and site classification.

8. Silviculture and harvesting methods and cost reduction.

9. Forest fire management and control.

10. Mixed-wood management.

The importance of research on wood processing and the development of new products were recognized but these matters were not rated because FRACC has not focused significant attention on them to date. Topics such as modern information handling systems, artificial intelligence, and biotechnology were judged important, but because they are considered primarily research tools, they were not rated.

Funding levels vary greatly across the country but funds provided through the federal-provincial agreements are vital everywhere. All of the priority subjects are considered to be underfunded to varying degrees, but this is particularly true for the first six topics.

Priorities have not changed dramatically during 4 years. Integrated resource management and decision support has been a high priority every year. It is significant that three subjects, all bearing on the environment, have moved up to priorities 2,3 , and 4 . These topics are pest and weed management and alternatives to chemicals, environmental effects of forest management, and ecological knowledge for intensive forest management. Silviculture and harvesting methods and cost reduction also increased in importance, whereas forest growth and yield data, and higher productivity, tree improvement, and regeneration declined. Research priorities are not changing faster than research agencies can adapt.
Twelve issues that will likely affect future research priorities were identified as follows:

1. Concern and input about sustainable forestry and the environment.

2. Managing nontimber values and a shrinking timber land base.

3. Global trade, competition, and world public opinion.

4. Underfunding and phase-out of federal-provincial agreements.

5. Accuracy of forest models for sustainable forestry.

6. Lack of data on the socioeconomic values of forests.

7. Land claims and forestry on aboriginal lands.

8. Intensive management of the boreal mixed-wood forest.

9. Economics of secondary forest products industry.

10. Increasing need for accurate information at all levels.

11. New provincial policies on forestry and forest protection.

12. Farm forestry for wood and shelterbelts.

Forestry research in Canada is considered well focused on requirements but improvement is needed in the local application of research results.

\section{Actions Stemming from Council's 1991 Report}

Forestry Canada has again provided a year-end report to FRACC regarding its action on FRACC's recommendations of the previous year. Council members are pleased that Forestry Canada is continuing this practice. The report is attached as Appendix II.

\section{Plan of Action for 1993}

Council will hold at least two regular meetings in 1993 in Ottawa and Montreal. During the year, it will attend to the following:

1. Continue consideration of global trends affecting forestry; attempt to set out a framework of five or six major issues requiring research attention and evaluate the general implications these have for forestry research priorities.

2. Attempt to define criteria for selecting research priorities.

3. Monitor the implementation of the Forest Sector Strategy with particular emphasis on the research aspects.

4. Monitor the updating of the Forestry Research Inventory.

5. Monitor Forestry Canada's work on a "Science and Technology Agenda" and continue to provide support and advice for this important initiative.

6. Promote and encourage greater involvement of provincial and territorial research advisory bodies in FRACC activities, particularly the preparation of the research priorities overview.

7. Review recommendations made by FRACC since its inception and assess their impact.

8. Consider further the matter of forest workers' attitudes and training and how these could be changed to incorporate environmental considerations in daily work planning and execution. 


\section{Appendix I. FRACC Membership for 1992}

\section{Provincial Representation}

Dr. Ted Baker

Director, Research Branch

British Columbia Forest Service

31 Bastion Square

Victoria, British Columbia

V8W 3E7

Mr. John Goodman

Assistant Deputy Minister, Administration

Ontario Ministry of Natural Resources

99 Wellesly Street West

Toronto, Ontario

M7A 1W3

\section{Jean-Guy Davidson}

Directeur de la recherche

et du développement

Ministère de l'Énergie et des Ressources

2700, rue Einstein, Bloc B.1.185

Sainte-Foy (Québec)

G1P 3W8

Mr. Ian Taviss

Tel: (506) 452-6932

Research Coordinator

New Brunswick Executive Research Council

H.J. Flemming Forestry Centre

Fredericton, New Brunswick

E3B $6 \mathrm{H} 6$

Mr. Murray Little

Saskatchewan Department of

Natural Resources

Forestry Branch

Box 3003

Prince Albert, Saskatchewan

S6V 6G1

\section{Industry Representation}

Mr. Jack W. Toovey, R.P.F.

(Chairman of FRACC through 1992)

2976 William Avenue

North Vancouver, British Columbia

V7K 1 Z6

Mr. Michael R. Innes

(Chairman Designate of FRACC, 1993-)

Manager of Forestry, Abitibi-Price Inc.

207 Queen's Quay West, Box 102

Toronto, Ontario

M5J 2P5

Mr. R.W. Udell, R.P.F.

Strategic Planning Superintendent

Weldwood of Canada Ltd.

760 Switzer Drive

Hinton, Alberta

T7V $1 \mathrm{~V} 7$

Mr. Gerald Lapointe

Woodlands Section

Canadian Pulp and Paper Association

1155 Metcalfe Street, 23rd Floor

Montreal, Quebec

H3B 4T6

Tel: (306) 953-2486

Tel: (418) 643-7994

Fax: (418) 643-2165

Tel: (416) 965-7106

Fax: (416) 324-3683

\section{il}

Tel: (604) 387-6720

Fax: (604) 387-0046

Professional Representation

Mr. W.J. Brown

General Manager

Algonquin Forestry Authority

222 Main Street West

Huntsville, Ontario

P0A $1 \mathrm{~K} 0$

\section{University Representation}

Dr. Peter J. Murphy

Faculty of Agriculture and Forestry

Department of Forest Science

University of Alberta

Edmonton, Alberta

T6G 2H1

Dr. Gilles Frisque, Director

Multiregional Forestry Research Centre

University of Quebec

2875 Laurier Blvd., 3rd Floor

Sainte-Foy, Quebec

G1V 2M3

\section{Members at Large}

M. Claude Godbout, Doyen

Faculté de foresterie et de géomatique

Université Laval

Québec (Québec)

G1K 7P4

Mr. Paul Griss

Address in 1992:

Canadian Nature Federation

453 Sussex Drive

Ottawa, Ontario

Tel: (604) 985-8680

Fax: (604) 985-8528

K1N $6 Z 4$

\section{Current Address:}

123 Walmer Road

Toronto, Ontario

M5R 2X8

Tel: (416) 369-6742

Fax: (416) 369-6745

Dr. Stan Rowe

P.O. Box 11

New Denver, British Columbia

V0G 1S0

Tel: (403) 865-2251

Mr. Jean Bérard

11480 , rue Pasteur

Montréal (Québec)

H3M 2P1
Fax: (403) 865-8129

\section{Ex Officio}

Dr. F.C. Pollett, Director General

Science and Sustainable

Development Directorate

Tel: (514) 866-6621

Fax: (514) 866-3035

Forestry Canada

Place Vincent Massey

351 St. Joseph Blvd.

Hull, Quebec

K1A 1 G5

Executive Secretary

Tel: (514) 334-7810
Dr. R.J. Bourchier

Cantley, Quebec

JOX 1L0
R.R. 1, P.O. Box 255
Tel: (403) 492-2359

Fax: (403) 492-4323

Home: (403) 458-9706

Tel: (418) 657-3551

Fax: (418) 657-2132

Tel: (418) 656-2116

Fax: (418) 656-3177

Tel: (613) 238-6154

Fax: (613) 230-2054

Tel: (416) 926-9721

Fax: (416) 926-9721

Tel: (604) 358-7170

Tel: (613) 997-1107

Fax: (613) 994-3389

Tel: (819) 827-0903 


\section{Appendix II. Forestry Canada Comments on FRACC Recommendations of 1991}

Recommendation 1. Forestry Canada agrees with this recommendation. Work at several of its establishments including the Petawawa National Forestry Institute, Northwest Region, and Pacific and Yukon Region is emphasizing incorporation of commodity and amenity values into forest management research. All of Forestry Canada's research that is linked to the Model Forests Network also addresses this need to some extent.

Recommendation 2. While Forestry Canada agrees with the general intent of this recommendation, it is mindful of the fact that curricula of all educational institutions are strictly a matter of provincial/territorial jurisdiction. Nevertheless, Forestry Canada continues to collaborate with forestry deans and directors, and with forestry researchers in nonforestry faculties, to develop a more multidisciplinary approach to forestry teaching and research. Forestry Canada researchers frequently provide enrichment to university courses in forestry and other fields, and several of Forestry Canada's establishments have Memoranda of Understanding (MOU's) with university forestry faculties to assist in coordination and enhancement of each other's programs. In addition, Forestry Canada has indicated its support for a forum on forestry education and training, as proposed by the Association of Dean/Directors of Schools of Forestry.

Forestry Canada strongly supports multidisciplinary programs such as the Tri-Council Eco-research Program, recently established under the federal Green Plan. In addition, the department will consult more closely with both the Natural Sciences and Engineering Research Council (NSERC) and the Social Sciences and Humanities Research Council (SSHRC) on the increasingly multidisciplinary scope and needs of forestry graduate and undergraduate programs and research projects.

Recommendation 3. Forestry Canada agrees in principle with this recommendation. Several of its recent programs, in particular the Green Plan Model Forests Network, have been designed to ensure that all stakeholders are directly involved in resource management decisions, from the planning stages to the implementation stages.

Recommendation 4. Forestry Canada agrees in principle with this recommendation, and will consider sponsoring such forums as part of its Human Resources Strategy.

Recommendation 5. Forestry Canada agrees with this recommendation and already does this, but will consider strengthening its efforts in this regard where opportunities and resources permit.

Recommendation 6. Forestry Canada accepts this recommendation. A database at the Petawawa National Forestry Institute has been developed on contract during the past year and is now undergoing final checking to ensure that it meets user needs. The final version should be ready by July 1993 . It will be updated regularly to ensure that reasonably current information is continuously available in future.

Recommendation 7. Forestry Canada agrees that all researchers must be aware of technology transfer needs and opportunities. Several research establishments are examining means of ensuring that scientists and technicians can relate to, and effectively participate in, the department's technology transfer and communications programs. The training and motivation of operational personnel is primarily a provincial and industry responsibility, but Forestry Canada will strive to ensure that its research results are communicated to those agencies in an effective and timely manner to assist them with their training and extension roles.

Recommendation 8. Forestry Canada agrees in principle with this recommendation and will incorporate economic and social criteria into the research planning and review processes where feasible and appropriate. A project review of the economics research program at Forestry Canada's Northwest Region has recently taken place, and the report of that review panel emphasized the increasing importance of Forestry Canada's economics and social research projects to the department's overall research program, and the need for more active collaboration between them. 